\title{
A LEGEND IN HIS OWN LIFETIME: DOUBLE NOBEL PRIZE WINNER LINUS PAULING
}

\author{
T. V. DANYLOVA ${ }^{1 \bowtie}$, S. V. KOMISARENKO \\ ${ }^{1}$ National University of Life and Environmental Sciences of Ukraine, Kyiv; \\ 凶e-mail: danilova_tv@ukr.net; \\ ${ }^{2}$ Palladin Institute of Biochemistry, National Academy of Sciences of Ukraine, Kyiv; \\ e-mail:svk@biochem.kiev.ua
}

Received: 19 April 2021; Accepted: 17 May 2021

Linus Pauling - a prominent American chemist, biochemist, chemical engineer, peace activist, author, and educator - was one of the scientists-humanists whose life echoed the key milestones of the 20th century and who could be compared with Leonardo da Vinci in terms of the breadth of interests and creative achievements. He is one of the four scientists to have won two Nobel Prizes (the Nobel Prize in Chemistry 1954; the Nobel Peace Prize 1962) and the only one to have been awarded two unshared Nobel Prizes. As a result of his long-lasting research, Pauling formulated a theory of structure and function of proteins; studied the effect of oxygen saturation of hemoglobin on its magnetic properties, laid the foundations for structural analysis of protein molecules, made a contribution to the study of antibodies. Believing that people had to develop a new type of thinking for the sake of the survival of humanity, Linus Pauling spoke out strongly against nuclear testing, and the contemporary world is indebted to Pauling for his courage and moral leadership in reminding us about the dangers of nuclear war. The versatile innovative activities of the brilliant scientist and humanist Linus Pauling, his unconventional personality, and the huge scientific heritage have left a deep mark in the history of humankind.

Ke y w ord s: Linus Pauling, Nobel Prize in Chemistry, Nobel Peace Prize, structure of proteins, Pauling's $\alpha$-helix, structure of DNA, vitamin $C$, fight against the nuclear arms race.

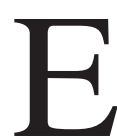
ach historical epoch is reflected in the lives of its representatives. Cultural-civilizational crisis affects the human identity and leads to the loss of the meaning of human existence. It's the time for humanity to revise the values and to "return to the vertical, to some spiritual ideal principle" [2] about which we can orient our lives [3]. The outlook of the epoch is intricately woven into our perception and behavior. Science as one of the main social institutions of society is a mirror that reflects the economic, political, social, and spiritual life of any given community, and its outstanding representatives are the beacons that determine the place of humanity in the ocean of chaos. One of the scientists-humanists whose life echoed the key milestones of the $20^{\text {th }}$ century and who could be compared with Leonardo da Vinci in terms of the breadth of interests and crea-

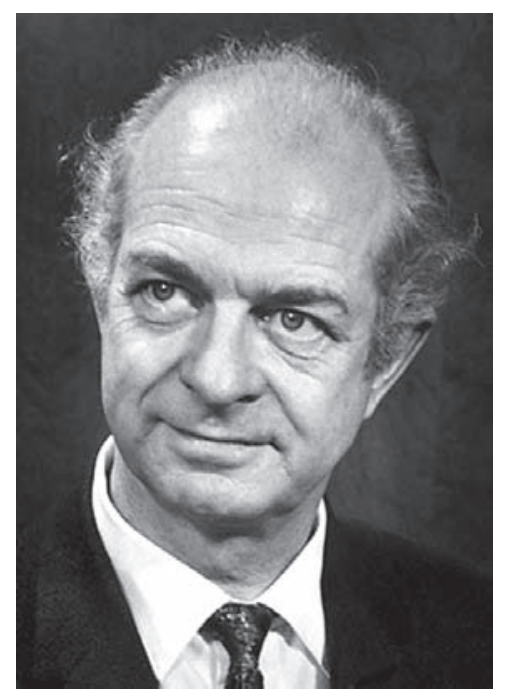

Linus Carl Pauling. Photo from the Nobel Foundation archive [1]

(C) 2021 Danylova T. V., Komisarenko S. V. This is an open-access article distributed under the terms of the Creative Commons Attribution License, which permits unrestricted use, distribution, and reproduction in any medium, provided the original author and source are credited. 
tive achievements was Linus Pauling (1901-1994) - a prominent American chemist, biochemist, chemical engineer, peace activist, author, and educator [4]. He is one of the four scientists to have won two Nobel Prizes (the Nobel Prize in Chemistry 1954; the Nobel Peace Prize 1962) and the only one to have been awarded two unshared Nobel Prizes [5, 6].

Linus Carl Pauling was born in Portland, Oregon, USA, on February 28, 1901, in the family of a druggist Herman Henry William Pauling and Lucy Isabelle Darling. Herman Pauling was of German descent and his wife Lucy - of English-Scottish ancestry. One of Linus Pauling's sisters, Pauline Darling Pauling, was born in 1902 and the other, Frances Lucile Pauling, in 1904.

In 1905, Pauling family moved to Condone, Oregon, and in 1906 Linus Pauling entered school there, where he especially enjoyed arithmetic and spelling.

In 1909, the family moved to Portland and little Linus attended the Clay school and then Glencoe School. In 1910, Linus and his sisters started attending Sunnyside Grammar School. Young Linus was a great reader deeply involved in the study of the ancient history and the natural sciences. From his early age, Linus Pauling was interested in all facets of the world, and this interest had run like a red thread throughout his life. His father died in 1910 and the family lost a drugstore he had owned. Because of money issues, Linus held different jobs after school. Unlike his father who nurtured boy's craving for knowledge, his mother guided him to earn money scorning his love for knowledge [8]. For young Pauling it was a road to nowhere, but good fortune saved him. His friend Lloyd A. Jeffress had a small chemistry lab. Going there, Linus was hooked. He described it later: "I was simply entranced by chemical phenomena, by the reactions in which substances, often with strikingly different properties, appear; and I hoped to learn more and more about this aspect of the world" [9].

In the high school, Linus Pauling took all the available science and math courses and had enough credits to enter the Oregon Agricultural College (known now as Oregon State University). Lacking two American history courses required for the school diploma and having received a refusal to take these courses concurrently during the college semester, he dropped out of the school without a diploma. $\mathrm{He}$ received it many years later. In 1917, Linus applied to the Oregon Agricultural College. He earned the degree of B.Sc. in Chemical Engineering in 1922.

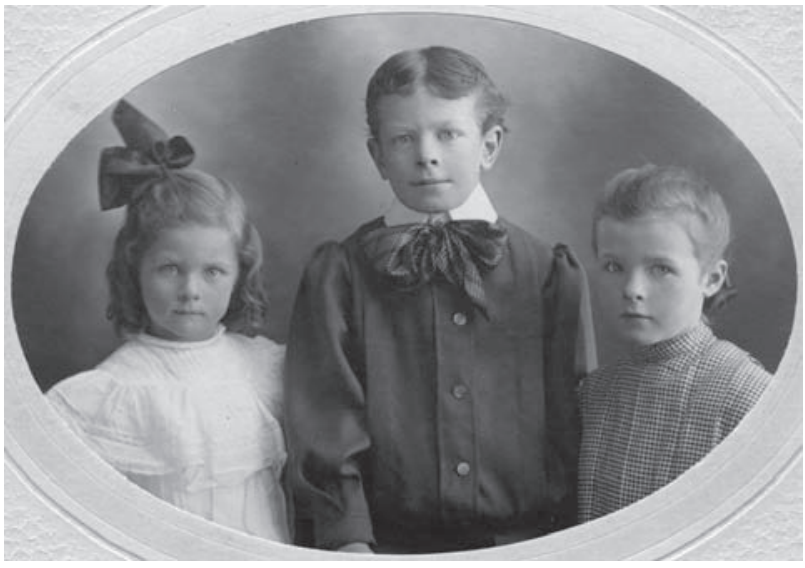

Pauline, Linus, and Lucile Pauling [7]

During his college time, Linus Pauling had to support his mother, and luckily the Chemistry Department offered him a job teaching the quantitative chemistry. In the class of women students of home economics, he met a bright and very attractive Ava Helen Miller who became his wife in 1923. Their happy marriage had lasted until Ava Helen's death in 1981. They had four children - Linus Carl Jr. who became a psychiatrist; Peter who was a crystallographer at University College London; Edward Crellin who was a biologist; and Linda Helen who became a geologist and glaciologist [11].

Linus Pauling highly appreciated Ava Helen's role in his life: "She was interested in the work that I was doing... She strove to take as many burdens as possible from my shoulders, in order that I could devote myself to my scientific and educational work as effectively as possible" $[12,13]$.

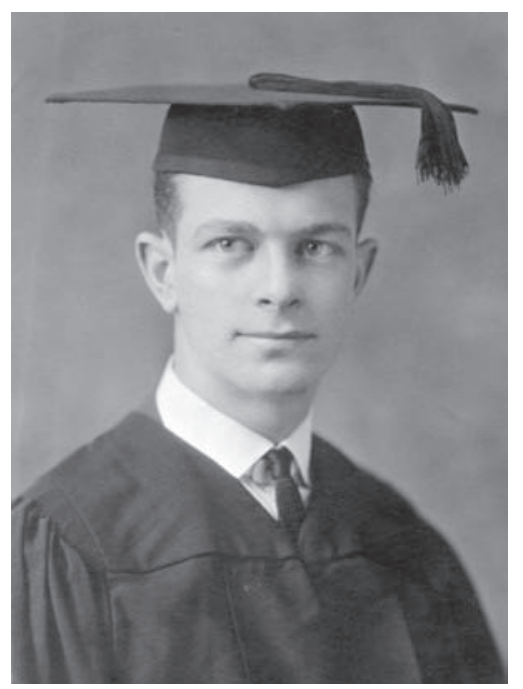

Pauling's graduation photo. 1922 [10] 
In 1922, Linus Pauling enrolled in the PhD Program at the California Institute of Technology (Caltech) where he was a graduate student working under Prof. R.G. Dickinson, who showed him how to determine the structures of crystals using X-rays, and R.C. Tolman [14]. "Perhaps no other school could have done as much for Pauling as Caltech did. Without question, he knew this was the place where he belonged, and where he discovered his life's work" [8]. In 1925, he was awarded the PhD in Chemistry with minors in Physics and Math for a dissertation derived from his crystal-structure papers. After a quite brief period of time as a National Research Fellow, Pauling received a Guggenheim Fellowship to study quantum mechanics in Europe. He studied with physicists who were exploring the implications of quantum physics for atomic structure [11]. Most of the time in Europe he spent at Arnold Sommerfeld's Institute for Theoretical Physics in Munich, Germany [15]. In Europe Linus Pauling also worked with E. Schrödinger in Zurich and N. Bohr in Copenhagen. Here Pauling found a physical and mathematical framework for his future theories.

Linus Pauling returned to Caltech in 1927 starting his career of research and teaching. At the age of 26 he became an Assistant Professor in theoretical chemistry, worked on X-ray crystal studies, and performed quantum mechanical calculations on molecules and atoms. Studying crystal structures and the types of bonding and coordination that occurred within them, Pauling found out that crystal structures obeyed the rules now known as Pauling's rules $[16,17]$. In his seminal paper "The Nature of the Chemical Bond and the Structure of Molecules and Crystals: An Introduction to Modern Structural Chemistry" [17], Linus Pauling reconstructed the foundations of chemistry - for the first time he explained the structure of molecules in terms of quantum mechanics. Linus Pauling described it this way: "From Richard C. Tolman, Harry Bateman, and other remarkable teachers at Caltech, I obtained an excellent grounding in chemistry, physics, and mathematics, with emphasis on the old quantum theory and atomic structure. Quantum mechanics was discovered a few months after I had received my $\mathrm{PhD}$ degree. The Schrödinger papers on wave mechanics were published about the time that I arrived at the Institute for Theoretical Physics (Professor Arnold Sommerfeld) at the University of Munich in April 1926. I immediately began to apply an approximate quantum mechanical treatment to the problem of the structure of atoms with many electrons and to simple molecules, making use of the treatments of the hydrogen molecule-ion and hydrogen molecule that had been formulated by $\varnothing$. Burrau, E.U. Condon, W. Heitler, and F. London.

These new ideas had applications to many aspects of chemistry. The applications included the nature of square, tetrahedral, and octahedral coordination complexes of metals; the stability of aromatic substances as determined by the resonance energy; the planarity of resonating and conjugated systems of single and double bonds; the secondary structures of proteins and the importance of the hydrogen bond in proteins, polynucleotides, and other substances; and the nature of interatomic forces in metals" [18].

In 1929, Pauling was promoted to Associate Professor, and in 1931, to Full Professor. This year he became the first recipient of the Langmuir Prize - the American Chemical Society Award in Pure Chemistry. It was the recognition of Pauling's productivity and talents, and the young researcher was described as the "prodigy of American science" [19, 20].

Pauling's interest in biological molecules, especially proteins, was stimulated in the late 1920s. He was inspired by the geneticist T.H. Morgan, who arrived at Caltech. However, he paid serious attention to biochemistry, namely the biochemistry of proteins, only in 1934. Pauling performed successful magnetic studies on the hemoglobin. Developing a deep interest in protein, he, together with an American scientist A.E. Mirsky, published a paper on general protein structure [21]. Since 1936 upto 1958, Linus Pauling had held senior management positions, such as a Chairman of the Division of Chemistry and Chemical Engineering and a Director of the Gates and Crellin laboratories of Chemistry [14]. As a result of his long-lasting research, Pauling formulated a theory of structure and function of proteins; studied the effect of oxygen saturation of hemoglobin on its magnetic properties, laid the foundations for structural analysis of protein molecules.

An Austrian-American immunologist and pathologist K. Landsteiner contributed to Pauling's interest in immunochemistry. Being thrilled by antibody-antigen reactions, Linus Pauling later developed a theory which explained the specificity of these reactions through a "unique folding of the antibody's polypeptide chain" [15].

Because of his contribution to the study of antibodies, he was chosen as the first Harrison Howe lecturer. In his talk, Pauling thanked K. Landsteiner 
for his experienced guidance: "Dr. Landsteiner, as well as Professor Michael Heidelberger, encouraged me, in 1940, to publish my first paper on the structure of antibodies and to begin experimental work in this field, and he followed the course of the work, carried on in Pasadena in collaboration with Dan H. Campbell, David Pressman, and several graduate students, and with the support of The Rockefeller Foundation, until his death in 1943" [22].

During World War II, J.R. Oppenheimer proposed Pauling to head the chemistry section of the Manhattan Project, but Pauling refused. Instead, he offered the US government his services as a research consultant. His project group originated a synthetic form of blood plasma for use in battlefield clinics. He designed the Pauling oxygen meter developed and manufactured by A.O. Beckman. The oxygen analyzers were adopted for use in incubators for premature babies after World War II. Linus Pauling was involved in the activity of a wartime presidential commission, which was formed to recommend the future directions of government-funded scientific and medical research programs. His patriotic activity was highly acknowledged by the government of the United States of America, and in 1948 President Harry Truman awarded the Presidential Medal for Merit to him for "extraordinary fidelity and exceptionally meritorious conduct" "in the performance of outstanding services to the United States from October, 1940 to June, 1946" [23].

After World War II, as a visiting professor at the University of Oxford, Linus Pauling returned to the problem he was deeply interested for many years, namely, the structure of proteins. He found out that the polypeptide chain would coil into a particular helical structure - the $\alpha$-helix. In PNAS papers, L. Pauling and R. B. Corey proposed the $\alpha$-helix and the $\beta$-sheet that formed the backbones of thousands of proteins [24]. The most significant aspect of Pauling's structure was its determination of the number of amino acids per turn of the helix. His theoretical configuration was based on "chemical-bonding considerations and $\mathrm{x}$-ray diffraction evidence from certain fibrous proteins" [11]. Eventually, Pauling's $\alpha$-helix was confirmed and has proved to be a real breakthrough [25].

At the same time, DNA had become a magnet that attracted the representatives of the various sciences. In the 1950s, there were three groups of researchers aimed at determining the structure of DNA. The first group at King's College, London, was led by M. Wilkins, while R. Franklin joined

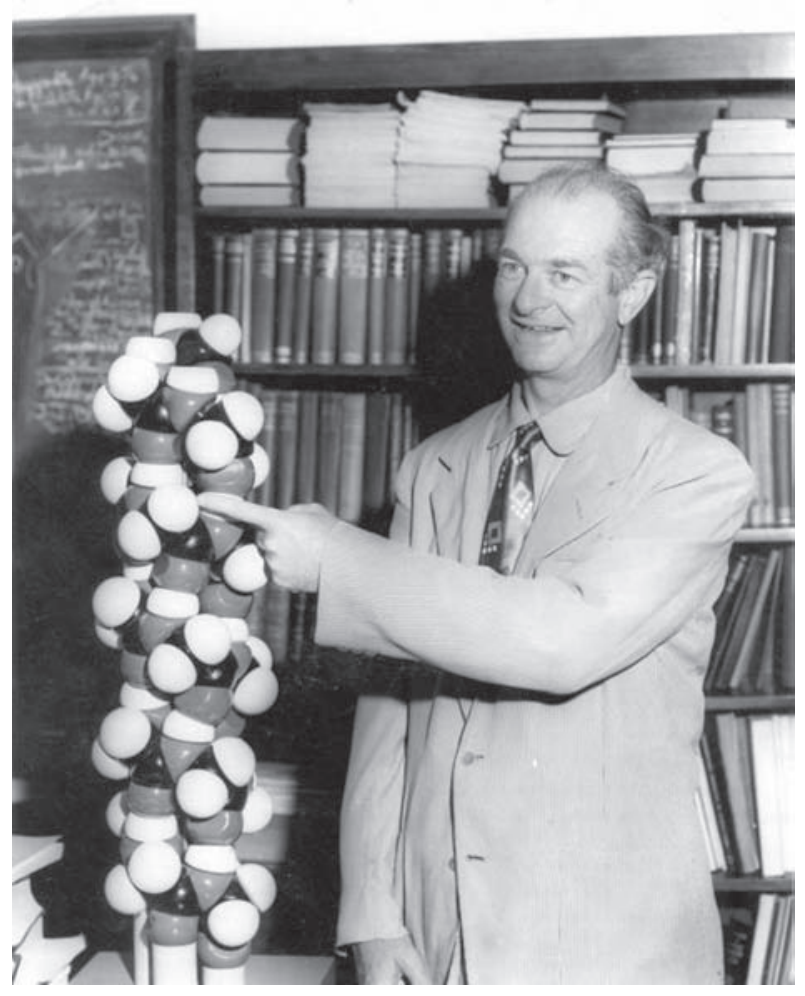

A model of the $\alpha$-helix [26]

this group later. They examined X-ray diffraction patterns of DNA fibers. Cambridge was represented by F. Crick and J. Watson. They were focused on building physical models [27]. Being involved in the study of the structure of DNA, Linus Pauling led Caltech group and discovered that many proteins included helical shapes [28].

In 1953, L. Pauling and R.B. Corey introduced their vision of a structure for DNA. They suggested a model for nucleic acids, including DNA, that consisted of three nucleic acid strands wound together in a triple helix [29]. Shortly thereafter, their successful competitors J. Watson and F. Crick proposed an accurate description of DNA double-helical structure [30]. Though Pauling's model appeared to be incorrect, his paper "A Proposed Structure for the Nucleic Acids" helped scientists "understand DNA's structure and function as genetic material" [31].

Despite this setback, Pauling's outstanding scientific discoveries were rewarded - the Nobel Prize in Chemistry 1954 was awarded to Linus Carl Pauling "for his research into the nature of the chemical bond and its application to the elucidation of the structure of complex substances" [32].

It would seem that Linus Pauling reached the pinnacle of his scientific career - the Nobel Prize. 


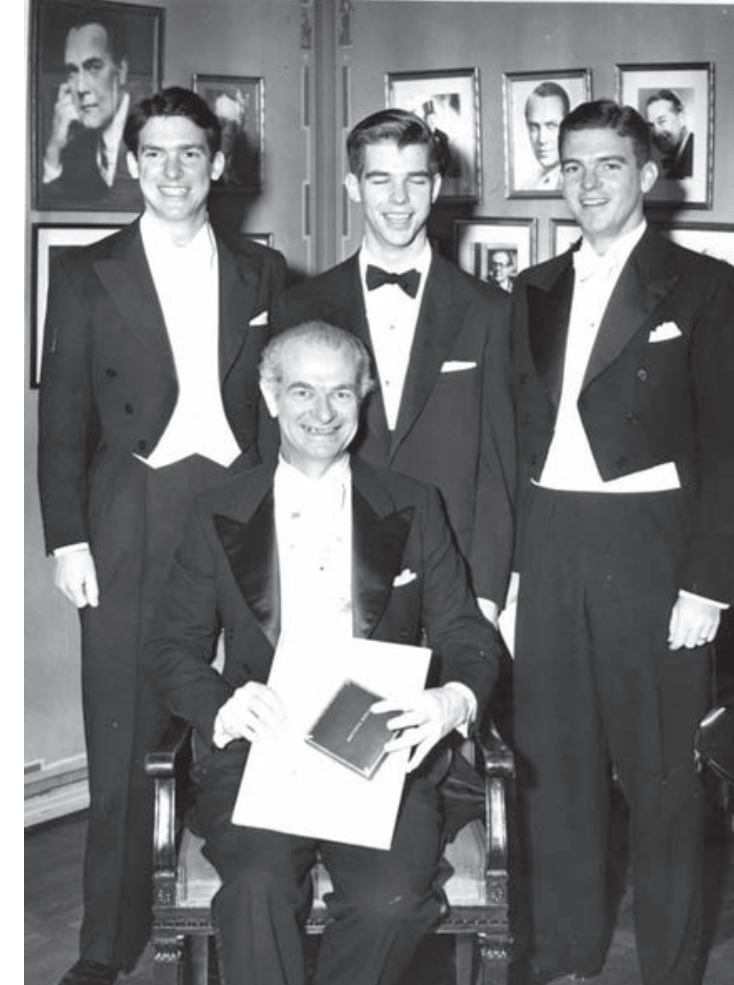

Linus Pauling and his sons at the Nobel Prize ceremony in Stockholm [33]

But his versatile personality and restless desire for knowledge and activities brought him to a different path - the path of the struggle for peace. After the atomic bomb was exploded over Hiroshima and Nagasaki in 1945, Pauling began thinking about the destructive implications of scientific development, as well as about the responsibility of scientists. Joining Albert Einstein's Emergency Committee of Atomic Scientists and believing that science and peace should be closely related, Linus Pauling started speaking out strongly against nuclear testing. The great scientist believed that it was his duty because most people were not aware of the dangers of nuclear testing as the government was trying to conceal it. In the Cold War time, this position was rather dangerous, and Pauling was treated as a traitor and for several years he was denied a passport to travel abroad. Only in 1954, his passport was restored that enabled him to visit Stockholm to be awarded with the Nobel Prize in Chemistry [11, 15].

However, Linus Pauling could not remain silent, he believed that people had to develop a new type of thinking for the sake of the survival of humanity. During 1950s Linus Pauling and his wife Ava Helen became well-known through their efforts to stop the atmospheric testing of nuclear weapons.

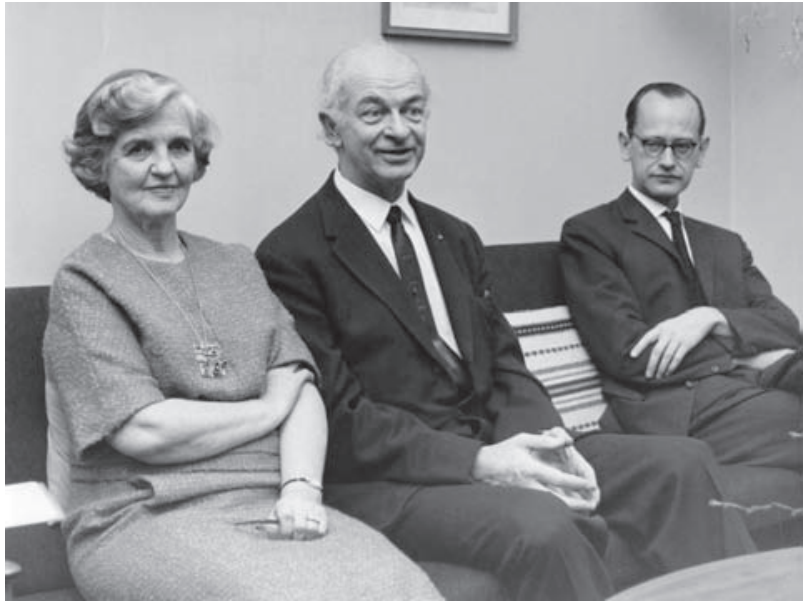

Ava Helen and Linus Pauling [34]

Over the years of their marriage, Ava Helen Pauling strongly supported her husband in his scientific work and in his struggle for peace.

In 1957, Pauling and his wife drafted a petition calling for the end to the atmosphere testing of nuclear weapons, and in 1958 they presented an appeal for the test ban signed by some 9000 and eventually more than 11000 scientists worldwide $[11,15,33]$. Linus Pauling also wrote the book "No More War!" [35], which became a bestseller. In 1960, he was forced to defend his actions on test ban before a congressional subcommittee. Despite the risk of being jailed, Pauling refused to name persons who had helped him collect signatures, "a stand initially condemned but later widely admired" [15].

In 1962, the president of the United States John Kennedy invited forty nine US Nobel Prize winners to the dinner that provided Linus Pauling with an opportunity to appeal to the president. The famous scientist led a protest near the White House carrying a placard "Mr. Kennedy. Mr. Macmillan. WE HAVE NO RIGHT TO TEST" [36].

Eventually Pauling's anti-testing activity was recognized with the 1962 Nobel Prize for Peace. It was awarded on October 10, 1963, the day that the Nuclear Test-Ban Treaty went into effect [15]. This belated Nobel Peace Prize was awarded to Linus Pauling "for his fight against the nuclear arms race between East and West" [37, 38].

Strongly believing in human rationality and universal peace, Linus Pauling stated in his Nobel Lecture: "We, you and I, are privileged to be alive during this extraordinary age, this unique epoch in the history of the world, the epoch of demarcation between the past millennia of war and suffering, and 


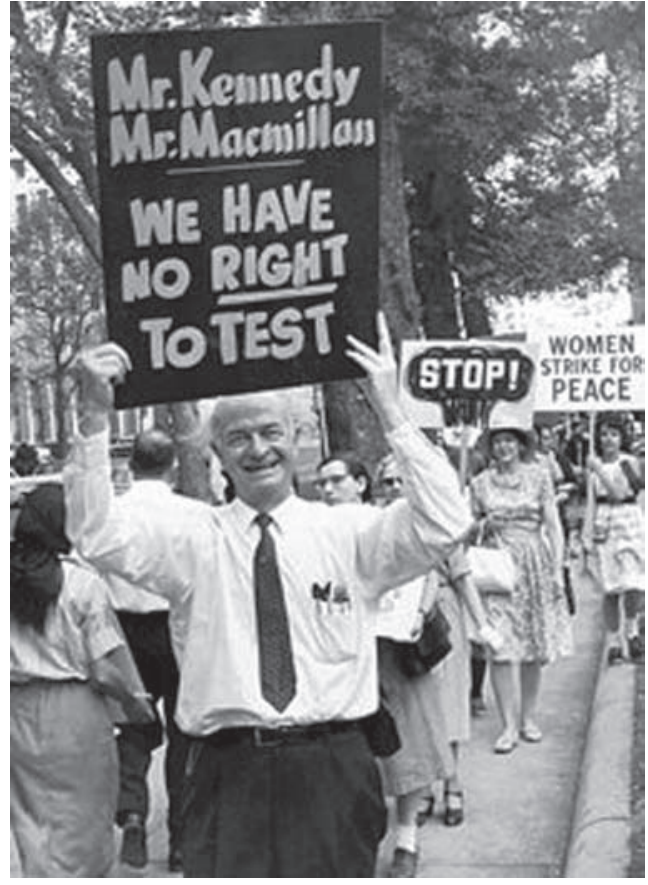

Linus Pauling [11]

the future, the great future of peace, justice, morality, and human well-being. We are privileged to have the opportunity of contributing to the achievement of the goal of the abolition of war and its replacement by world law. I am confident that we shall succeed in this great task; that the world community will thereby be freed not only from the suffering caused by war but also, through the better use of the earth's resources, of the discoveries of scientists, and of the efforts of mankind, from hunger, disease, illiteracy, and fear; and that we shall in the course of time be enabled to build a world characterized by economic, political, and social justice for all human beings and a culture worthy of man's intelligence" [39].

Though the dreams about the realm of reason have never become reality that is evidenced by the terrible social, political, economic cataclysms of the last decades, the world is indebted to Linus Pauling for his courage and moral leadership in reminding us about the dangers of nuclear war.

The struggle for peace cost Pauling his friends, funding, and his job. In the US media Linus Pauling was branded as "the eccentric Dr. Pauling" whose "weird politics has never been taken seriously by American opinion" [40]. Even a headline in Life magazine described 1962 Nobel Peace Prize as "a weird insult from Norway" [40]. In 1964, Linus Pauling left his tenured professorship at Caltech because of pressure from the University administration and some of the trustees who didn't support and approve his peace-making activity. He had spent three years at the center for the Study of Democratic Institutions and in 1967 he moved to the University of California at San Diego [9]. From 1969 to 1974, he had accepted a position as Professor of Chemistry at Stanford University. In 1973, Linus Pauling founded the Linus Pauling Institute of Science and Medicine in Palo Alto and there he centered his activities [9]. From here on, Pauling is best known as a strong proponent of vitamin $\mathrm{C}$. Becoming deeply interested in the role of nutrition in health, he advocated for the idea of treating diseases with vitamin supplements, in particular, vitamin C. In his book "Vitamin C and the Common Cold", which was published in 1970, Pauling recommended high doses of vitamin $\mathrm{C}$ to prevent colds or lessen their symptoms [41]. Elaborating his new scope of interest, he published "Vitamin C, the Common Cold, and the Flu" (1976) [42], "Cancer and Vitamin C: A Discussion of the Nature, Causes, Prevention, and Treatment of Cancer with Special Reference to Vitamin C" (1979, coauthored with E. Cameron) [43], "How to Live Longer and Feel Better" (1986) [44]. Linus Pauling coined the term "orthomolecular", which means the right molecules in the right amounts. His ideas formed the basis of orthomolecular medicine. His unorthodox ideas were severely criticized and have generated much controversy. Despite medical community criticism, the great scientist continued promoting vitamin $\mathrm{C}$ for treating diseases; he worked with The Institutes for the Achievement of Human Potential to use vitamin $\mathrm{C}$ in the treatment of brain-injured children [45]. Nowadays, the re-evaluation of Linus Pauling's research has shown that "dietary supplementation with antioxidants such as vitamin $\mathrm{C}$ can have significant beneficial effects on health. Pauling's ideas about molecular balance and health are increasingly important to a health-conscious public, as well as to a growing number of health professionals" [46].

The last few years of his life, Linus Pauling spent at his coastal ranch and his apartment at Stanford. His wife Ava Helen Pauling died of stomach cancer in 1981. In tribute to her commitment to peace in the world, the Ava Helen and Linus Pauling Lectureship in World Peace has been established in Oregon State University. In 2001 to honor Ava Helen Pauling's memory, the Linus Pauling Institute established the endowed Ava Helen Pauling Chair [11].

On August 19, 1994, Linus Pauling died of prostate cancer at his home in Big Sur, California. 


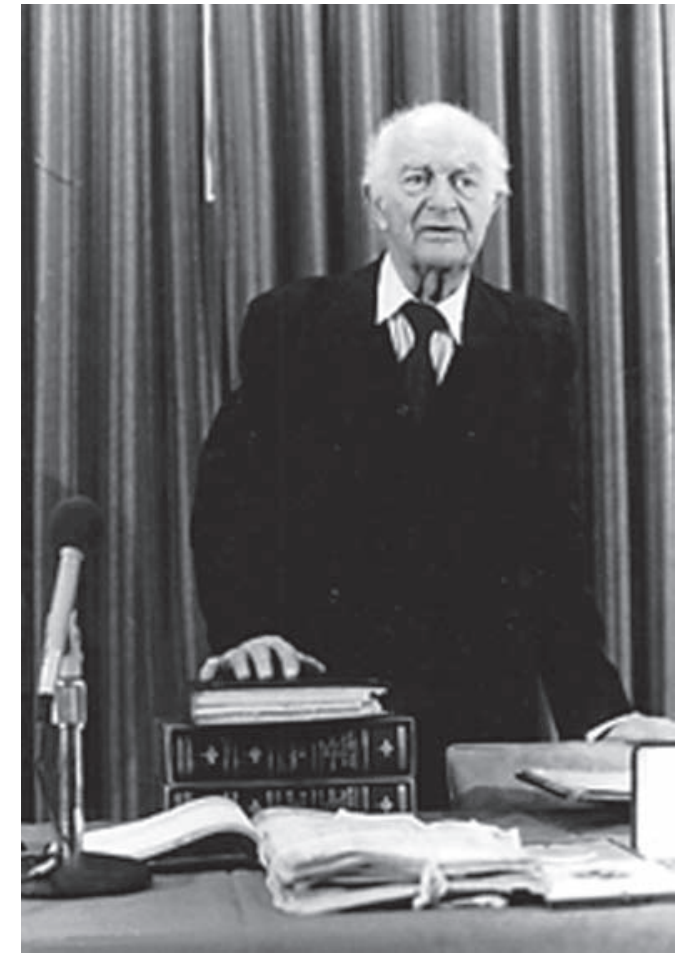

Linus Pauling [11]

A cenotaph was placed in the Pauling family plot in the Oswego Pioneer Cemetery by his sister Pauline. However, only in 2005, Pauling's ashes, along with those of his wife, were moved from Big Sur to the Oswego Pioneer Cemetery [47, p. 2].

Linus Carl Pauling has been recognized with numerous awards and honors, including Langmuir Prize, American Chemical Society (1931); Nichols Medal, New York Section, American Chemical Society (1941); Davy Medal, Royal Society (1947); United States Presidential Medal for Merit (1948); Pasteur Medal, Biochemical Society of France (1952); Nobel Prize, Chemistry (1954); Addis Medal, National Nephrosis Foundation (1955); Phillips Memorial Award, American College of Physicians (1955); Avogadro Medal, Italian Academy of Science (1956); Paul Sabatier Medal (1957); Pierre Fermat Medal in Mathematics (1957); International Grotius Medal (1957); Nobel Peace Prize (1963); Order of Merit, Republic of Italy (1965); Medal, Academy of the Rumanian People's Republic (1965); Linus Pauling Medal (1966); Silver Medal, Institute of France (1966); Supreme Peace Sponsor, World Fellowship of Religion (1966); United States National Medal of Science (1972); International Lenin Peace Prize (1972); Lomonosov Medal, USSR Academy of Science (1978); Medal for Chemical Sciences, Na- tional Academy of Science (1979); Priestley Medal, American Chemical Society (1984); Award for Chemistry, Arthur M. Sackler Foundation (1984); Award in Chemical Education, American Chemical Society (1987); Vannevar Bush Award, National Science Board (1989); Richard C. Tolman Medal, Southern California Section, American Chemical Society (1990) [48].

The versatile innovative activities of the brilliant scientist and humanist Linus Pauling have left a deep mark in the history of humankind. Therefore, it is no coincidence that his name has been immortalized. In 2008, the United States Postal Service released a stamp honoring Linus Pauling [49]. On December 15, 2008, Linus Pauling was inducted into the California Hall of Fame. One of the greatest scientists of all times was represented by his eldest son, Dr. Linus Pauling [50]. By proclamation of Gov. John Kitzhaber, February $28^{\text {th }}$ is "Linus Pauling Day" in the state of Oregon [51]. In 1991, the asteroid 4674 Pauling in the inner asteroid belt was named after Linus Pauling on the occasion of his ninetieth birthday [52].

In 1996, the Linus Pauling Institute moved from Palo Alto, California, to Corvallis, Oregon, where it is a part of the Linus Pauling Science Center at Oregon State University. The Linus Pauling Institute's mission "is to promote optimal health through cutting-edge nutrition research and trusted public outreach" [53].

Linus Pauling stated that he had "always liked working in some scientific direction that nobody else is working in" [33]. As a pioneer, he was way ahead of his time. His versatile activities, unconventional personality and the huge scientific heritage are an important chapter in the book of human history.

\section{ЛЕГЕНДА СВОГО ЧАСУ: ДВІЧІ ЛАУРЕАТ НОБЕЛІВСЬКОЇ ПРЕМІЇ ЛАЙНУС ПОЛІНГ}

\section{T. В. Данилова ${ }^{1 \bowtie}$, С. В. Комісаренко ${ }^{2}$}

$$
\begin{gathered}
{ }^{1} \text { Національний університет біоресурсів і } \\
\text { природокористування України, Київ; } \\
\text { e-mail: danilova_tv@ukr.net; } \\
{ }^{2} \text { Інститут біохімії ім. О. В. Палладіна } \\
\text { НАН України, Київ; } \\
\text { e-mail: svk@biochem.kiev.ua }
\end{gathered}
$$

Лайнус Полінг - видатний американський хімік, біохімік, інженер-хімік, активіст, автор і педагог - був одним із вчених-гуманістів, жит- 
тя яких перегукувалося 3 ключовими віхами $\mathrm{XX}$ століття, i якого можна порівняти 3 Леонардо да Вінчі $з$ позиції широти інтересів та творчих досягнень. Він $є$ одним із чотирьох вчених, які отримали дві Нобелівські премії (Нобелівська премія 3 хімії 1954 р.; Нобелівська премія миру 1962 р.), і він єдиний, хто отримав ці дві премії одноосібно. Внаслідок своїх тривалих досліджень Полінг сформулював теорію структури та функції протеїнів; вивчив вплив насичення киснем гемоглобіну на його магнітні властивості, заклав основи структурного аналізу молекул протеїнів, зробив внесок у вивчення антитіл. 3 вірою в те, що людям необхідно розвинути новий тип мислення задля виживання всього людства, Лайнус Полінг рішуче виступав проти ядерних випробувань, і сучасний світ вдячний Полінгу за моральне лідерство i мужність нагадати нам про небезпеку ядерної війни. Різнобічна інноваційна діяльність блискучого вченого і гуманіста Лайнуса Полінга, його непересічна особистість та величезна наукова спадщина залишили глибокий слід в історії людства.

К л ючов в с лов а: Лайнус Полінг, Нобелівська премія 3 хіміі, Нобелівська премія миру, структура протеїнів, $\alpha$-спіраль Полінга, структура ДНК, вітамін C, боротьба з перегонами ядерних озброєнь.

\section{References}

1. Linus Pauling. Facts. The Nobel Prize. 1962. Regime of access: https:/www.nobelprize.org/ prizes/peace/1962/pauling/facts/.

2. Cairns GE. The philosophy and psychology of the oriental mandala. Philos East West. 1962; 11(4): 219-229.

3. Danylova TV, Komisarenko SV. Born in Ukraine: Nobel prize winners Ilya Mechnikov, Selman Waksman, Roald Hoffmann and Georges Charpak. Ukr Biochem J. 2019; 91(3): 127-137.

4. Danilova VM, Vynogradova RP, Komisarenko SV. The contribution of Nobel Prize laureates to research of the protein structure: J. Sumner, J, Northrop, W. Stanley, L. Pauling, F. Sanger, M. Perutz, J. Kendrew. Ukr Biochem J. 2020; 92(4): 127-153.

5. Nobel Prize facts. The Nobel Prize. 2020. Regime of access: https:/www.nobelprize.org/ prizes/facts/nobel-prize-facts/.
6. Danylova TV, Komisarenko SV. Double Nobel Prize winner: Frederick Sanger - the father of genomics. Ukr Biochem J. 2021; 93(2): 116-122.

7. Linus Pauling's Childhood (1901-1910). Special Collections \& Archives. OSU Libraries. Regime of access: http://scarc.library.oregonstate.edu/ coll/pauling/chronology/page3.html.

8. Valiunas A. The Man Who Thought of Everything. The New Atlantis. 2015. Regime of access: https:/www.thenewatlantis.com/publications/ the-man-who-thought-of-everything.

9. Abrams I. The Nobel Peace Prize and the Laureates. All Illustrated Biographical History. USA: Science History Publications, 2001. 350 p.

10. Linus Pauling. (2021). Wikipedia. Regime of access: https://en.wikipedia.org/wiki/Linus Pauling.

11. Linus Pauling Biography. Oregon State University. Regime of access: https://pi.oregonstate.edu/ about/linus-pauling-biography.

12. The Pauling's Wedding Anniversary. The Pauling Blog. 2008. Regime of access: https:// paulingblog.wordpress.com/2008/06/17/thepaulings-wedding-anniversary/.

13. Pauling L. An Episode that Changed My Life. Unpublished typescript by Linus Pauling recounting Ava Helen Pauling's impact upon his peace activism. 1980s. Linus Puling and the International Peace Movement. Regime of access: http://scarc.library.oregonstate.edu/coll/ pauling/peace/notes/NDa.23.html.

14. Linus Pauling. Biographical. The Nobel Prize. 1954. Regime of access: https://www. nobelprize.org/prizes/chemistry/1954/pauling/ biographical/.

15. Paradowski PJ. Linus Pauling. American Scientist. Encyclopedia Britannica. Regime of access: https://www.britannica.com/biography/ Linus-Pauling.

16. Pauling L. The Principles Determining the Structure of Complex Ionic Crystals. J Am Chem Soc. 1929; 51(4): 1010-1026.

17. Pauling L. The Nature of the Chemical Bond and the Structure of Molecules and Crystals: An Introduction to Modern Structural Chemistry. Ithaka, NY: Cornell University Press, 1939. 429 p.

18. Linus Pauling. This Week's Citation Classics. Current Contents. 1985: 4. Regime of access: http:/garfield.library.upenn.edu/classics1985/ A1985TZ93600001.pdf. 
19. The Langmuir Prize. Linus Pauling. The Nature of the Chemical Bond. Regime of access: http:// scarc.library.oregonstate.edu/coll/pauling/bond/ narrative/page28.html.

20. Pictures and Illustrations. Linus Pauling. The Nature of the Chemical Bond. Regime of access: http://scarc.library.oregonstate.edu/coll/pauling/ bond/pictures/index.html.

21. Mirsky AE, Pauling L. On the Structure of Native, Denatured, and Coagulated Proteins. Proc Natl Acad Sci USA. 1936; 22(7): 439-447.

22. Pauling L. Analogies between Antibodies and Simpler Chemical Substances. Chem Eng News. 1946; 24(8): 1064-1065.

23. Presidential Medal for Merit (1948). Linus Pauling: Awards, Honors and Medals. Regime of access: http://scarc.library.oregonstate.edu/ coll/pauling/awards/1948h.1.html.

24. Pauling L, Corey RB, Branson HR. The structure of proteins: Two hydrogen-bonded helical configurations of the polypeptide chain. Proc Natl Acad Sci USA. 1951; 37(4): 205-211.

25. Hargittai I. Linus Pauling's quest for the structure of proteins. Struct Chem. 2010; 21(1): 1-7.

26. Pictures and Illustrations. Linus Pauling and the Structure of Proteins. Regime of access: http://scarc.library.oregonstate.edu/coll/pauling/ proteins/pictures/1954i.38.html.

27. Danylova TV, Komisarenko SV. Standing on the shoulders of giants: James Watson, Francis Crick, Maurice Wilkins, Rosalind Franklin and the birth of molecular biology. Ukr Biochem J. 2020;92(4):154-165.

28. Navarro, S. Molecular Biology Gene to Proteins. ED-TECH Press, 2018. 308 p.

29. Pauling L, Corey RB. A Proposed Structure For The Nucleic Acids. Proc Natl Acad Sci USA. 1953; 39(2): 84-97.

30. Matyshevska OP, Danilova TV, Komisarenko SV. The discovery of the DNA double helix, or the revolution that ushered in the era of molecular biology (Nobel Prize 1962). Ukr Biochem J. 2020; 92(6): 183-198.

31. Hernandez, V. "A Proposed Structure for the Nucleic Acids" (1953) by Linus Pauling and Robert Brainard Corey. The Embryo Project Encyclopedia. 2019. Regime of access: https:// embryo.asu.edu/pages/proposed-structurenucleic-acids-1953-linus-pauling-and-robertbrainard-corey.
32. The Nobel Prize in Chemistry 1954. The Nobel Prize. Regime of access: https://www.nobelprize. org/prizes/chemistry/1954/summary/.

33. Linus C. Pauling, Ph.D. Academy of Achievement. Regime of access: https://achievement.org/ achiever/linus-pauling/.

34. Alpkunt B. Linus Pauling. Architect of structural chemistry, and an activist. Science \& People. Evren Atlasi. 2020. Regime of access: https:// evrenatlasi.com/en/2020/11/who-is-linuspauling/.

35. Pauling L. No More War! Dodd, Mead, 1958. $254 \mathrm{p}$.

36. Agre PC. Fifty Years Ago: Linus Pauling and the Belated Nobel Peace Prize. 2013. Science \& Diplomacy. AAAC Center for Science Diplomacy. Regime of access: https://www. sciencediplomacy.org/letter-field/2013/fiftyyears-ago-linus-pauling-and-belated-nobelpeace-prize.

37. The Nobel Peace Prize 1962. The Nobel Prize. Regime of access: https://www.nobelprize.org/ prizes/peace/1962/summary/.

38. Nobel Prize for Peace. Certificate. (1963). Linus Pauling. Awards, Honors and Medals. Regime of access: http://scarc.library.oregonstate.edu/ coll/pauling/awards/1963h2.1-certificate.html.

39. Pauling L. (1963). Science and Peace. Linus Pauling Nobel Lecture. The Nobel Prize. Regime of access: https://www.nobelprize.org/ prizes/peace/1962/pauling/lecture/.

40. A Weird Insult from Norway. Life. Vol.5. No. 17. October 25. 1963.

41. Pauling L. Vitamin $\mathrm{C}$ and the Common Cold. W.H. Freeman and Company, 1970. 122 p.

42. Pauling L. Vitamin C, the Common Cold, and the Flu. Freeman \& Co., 1976. 230 p.

43. Cameron E, Pauling L. Cancer and Vitamin C: A Discussion of the Nature, Causes, Prevention, and treatment of Cancer with Special Reference to Vitamin C. Linus Pauling Institute of Science and Medicine, 1979. $240 \mathrm{p}$.

44. Pauling L. How to Live Longer and Feel Better. Oregon State University Press, 2006. 338 p.

45. Pauling L. Orthomolecular enhancement of human development. In: Pelligra R. (Ed). Human Neurological Development: Part, Present, and Future. NASA Conference Publication. 1978: 2063: 47-51. 
46. Promoting Vitamin C. Linus Pauling. The Linus Pauling Papers. U.S. National Library of Medicine. Regime of access: https://profiles. nlm.nih.gov/spotlight $/ \mathrm{mm} /$ feature/medicine.

47. Who's Buried in Linus Pauling's Grave? The Centennial. July1, 2010. Regime of access: https://www.ci.oswego.or.us/sites/default/files/ fileattachments/publicaffairs/webpage/13678/ centennial_july2010.pdf.

48. Linus Pauling, interview by Jeffrey L. Sturchio at Executive Tower Inn, Denver, Colorado, 6 April 1987 (Philadelphia: Chemical Heritage Foundation, Oral History Transcript \# 0067).

49. Four Legends of American Science Now on U.S. Postage Stamps. United States Postal Service. Postal News. Release No. 08-23. March 6, 2008. Regime of access: https://about.usps.com/news/ national-releases/2008/sr08_023.pdf.
50. Governor \& First Lady participate in 2008 CA Hall of Fame Induction Ceremony. CA. gov. Archived from the original on June 2, 2015. Regime of access: https://web.archive.org/ web/20150602035158/http:/gov.ca.gov/news. php?id=11255.

51. Linus Pauling Research Notebooks Online. Natural Science. Archived from the original on September 5, 2015. Regime of access: https:// web.archive.org/web/20150905114549/http:// naturalscience.com/ns/news/news $40 . h t m l$.

52. Schmadel LD. Dictionary of Minor Planet Names. Springer, 2016. 1464 p.

53. About the Linus Pauling Institute. Linus Pauling Institute. Oregon State University. Regime of access: https://lpi.oregonstate.edu/about/aboutlinus-pauling-institute. 